\title{
BUNGA BANK : ABDULLAH SAEED VS YUSUF QARADHAWI \\ (Sebuah Dialektika Pemikiran antara Kaum Modernis dengan Neo-Revivalis) \\ Wartoyo $^{1}$
}

\begin{abstract}
Abstrak
This article aims to discuss the term of riba in the modernist and neo-revivalists thought as represented in Abdullah Saeed and Yusuf Qaradhawi different opinion on it. The difference between the modernist and neo-revivalists in usury problem stems from differences in the understanding and interpretation of the verses of the Koran that speak about it. Contextuality of the modernists put the text forward the law, so that the conventional view that bank interest is not the same as usury, while the neo-revivalist view that the problem of usury should be seated as a final assessment as mentioned in the Koran, in which each of the additional capital is usury and haram.
\end{abstract}

Keyword: Riba, interest, Modernis, Revivalis.

\section{Pendahuluan}

Perbincangan mengenai riba dalam khazanah pemikiran Islam, selalu saja memunculkan perbedaan pandangan di antara para cendikiawan muslim, baik itu pada masa klasik, masa pertengahan, hingga masa modern sekarang ini. Perbedaan pandangan tersebut timbul, terutama pada masa modern sekarang ini, dikarenakan masih belum adanya keseragaman pemikiran dan pandangan dari para cendekiawan muslim mengenai hukum bunga bank. Apakah bunga bank tersebut termasuk riba, sebagaimana yang ditegaskan oleh para teoritisi perbankan syari'ah, yang diprakarsai oleh cendikiawan-cendikiawan muslim kelompok tradisionalis, ${ }^{2}$ yang memiliki pemikiran lebih konservatif. Ataukah bukan riba, seperti yang coba dijelaskan secara kritis oleh cendikiawan-cendikiawan muslim lainnya, yang tergabung dalam kelompok modernis $^{3}$.

${ }^{1}$ Dosen Fakultas Ekonomi pada Informatic and Business Institute (IBI) Darma Jaya Bandar Lampung. E-mail: san_diero2000@yahoo.com.

${ }^{2}$ Para ulama tradisionalis, adalah kelompok para ulama yang berpegang teguh pada pemikiran bahwa, setiap aturan hukum yang secara jelas dan terang telah dinyatakan dalam nash, maka manusia harus mengikutinya. Sedangkan bagi hukum-hukum lain yang belum terdapat nash secara pasti, maka wajib bagi manusia untuk berijtihad, dengan berpegang pada hukum yang paling dekat dengannya. Lihat Abdullah Saeed (2006). Islamic Thought, An Intoduction (New York: Routledge), p. 134-141.

${ }^{3}$ Gerakan ini muncul pada paruh abad XIX M. Para modernis dalam memahami sebuah fenomena tertentu selalu memperhatikan situasi dan kondisi yang melatarbelakangi munculnya fenomena tersebut, baik itu dari segi moral, agama, maupun setting sosial-historis dalam menjawab 
Bila ditilik ke belakang, perbedaan pandangan yang muncul pada awalnya berkisar seputar, apakah semua jenis riba itu haram atau tidak. Perbedaan ini, misalnya bisa kita telusuri dari interpretasi yang cukup beragam dari para mufasir. Dalam hal ini, terdapat sebagian mufasir, yang secara tegas melarang semua jenis riba, baik itu riba yang berlipatganda (adh'äfan mudhäâfatan), maupun riba yang sedikit, baik itu riba nasi'ah ataupun riba fadhl. Menurut pandangan mereka, riba nasi'ah atau riba jahiliyah, dilarang berdasarkan perintah nash yang pasti, sedangkan riba fadhl, dilarang karena bisa menjadi jalan, bagi terciptanya riba nasi'ah.

Mufasir yang termasuk dalam kelompok ini, antara lain adalah Al-Jhassās ${ }^{4}, \mathrm{Al}-$ Qurthūbi ${ }^{5}$ As-Syaūkani ${ }^{6}$, dan Saŷyid Qûtb. ${ }^{7}$ Pandangan mufasir kelompok pertama ini, pada intinya memandang bahwa, penyebutan kalimat adh'äfan mudhäâfatan, bukanlah merupakan syarat atau batasan terhadap pelarangan riba, melainkan berfungsi sebagai informasi, dan gambaran praktek yang ada di dalam masyarakat Arab pra-Islam, yang melakukan praktik riba secara keji terhadap orang-orang yang lemah. ${ }^{8}$ Pandangan ini, kemudian diikuti dan dipertegas lagi oleh pendapat para pemikir Islam sesudahnya, seperti Abu A'la Al-Maûdūdi 9', Nejatullah As-Shiddiqie ${ }^{10}$, dan lain-lain. Mereka umumnya berpandangan bahwa, setiap tambahan dari pokok pinjaman, sedikit ataupun banyak adalah dilarang, karena itulah riba.

Sedangkan sebagian mufasir yang lain, berpandangan sedikit berbeda. Mereka berpendapat bahwa, hanya riba jenis jahiliyah atau nasi'ah saja yang haram, sedangkan riba jenis lainnya (fadhl) tidak diharamkan. Mereka mendasarkan pendapatnya pada argumen, bahwa kalimat adh'âfan mudhäâfatan merupakan syarat haramnya riba, maka bila ada penambahan yang tidak berlipatganda, hukumnya tidak dilarang, seperti penambahan pada jual beli misalnya, baik itu dibayar segera maupun tangguh.

berbagai problemmantika kehidupan. Lihat Rahman (1985). Islam and Modernity (Chicago: The University of Chicago Press), p. 2-19.

${ }_{4}^{4}$ Abi Bakr Ahmad bin Ali Al-Razi Al-Jhassās (tt). Ahkam Al-Qur'an, jilid I (Beirut: Daarul Kutub Al-Ilmiah), p. 563-567.

5 Imam Abu Abdullah Muhammad bin Ahmad Al-Anshari Al-Qurthūbi (1993). Al-Jami' AlAhkam min Al-Qur'an, jilid II (Beirut: Daarul Kutub Al-Ilmiah), p. 225-238.

${ }^{6}$ Muhammad bin Ali bin Muhammad As-Syaukani (2002). Fathul Qadir, juz I (Riyadh, Maktabah Ar-Rusyd), p. 262-267

${ }^{7}$ Sayyid Muhammad Qutb (1992). Fi Dzilali Al-Qur'an, juz III, jilid I (ttp: Daarus Syuruk), p. 318-332.

${ }^{8}$ Khoiruddin Nasution (1996). Riba dan Poligami, sebuah studi atas pemikiran Muhammad Abduh (Yogyakarta: Pustaka Pelajar), p. 40-49

${ }^{9}$ Abu A'la Al-Maûdūdi (tt). Al-Riba (Hyderabad: Daarul Fakir), p. 10 dst.

${ }^{10}$ Muhammad Nejatullah As-Shiddiqi (1983). Banking Without Interest (Liecester: Islamic Foundation), p. 18 dst. 
Kelompok mufasir yang berpandangan demikian, di antaranya adalah At-Thabāri ${ }^{11}$, AlMarāghî ${ }^{12}$, dan Rashîd Ridhâ. ${ }^{13}$

Berkaitan dengan wacana di atas, tulisan ini memfokuskan pada apa yang ditawarkan oleh Abdullah Saeed dan Yûsuf Al-Qaradhāwi. Kedua pemikir kontemporer ini, sama-sama menawarkan pendekatan yang relatif baru dalam kajian Al-Qur'an mengenai masalah riba, yang tentu saja memiliki relevansi yang erat dengan bunga bank. Yakni dengan menggunakan dasar-dasar teori ijtihad modern, meskipun masingmasing menekankan pada aspek yang berbeda. Abdullah Saeed cenderung pada penggunaan landasan moral, dengan melakukan analogi (qiyas) berdasarkan hikmah, bukan illat. $^{14}$ Ini tampak dalam analisisnya, mengenai aspek-aspek pelarangan riba dalam Al-Qur'an dan juga sunnah. Sehingga berimplikasi pada pandangannya, bahwa bunga bank konvensional adalah boleh, karena tidak mengandung unsur-unsur yang merupakan tujuan utama pelarangan riba. Di mana menurutnya, unsur utama dalam aspek pelarangan riba dalam Al-Qur'an, adalah terciptanya kedzaliman yang dinyatakan dengan jelas dalam kalimat, là taźlimūna wa là tuźlàmūn. ${ }^{15}$

Sedangkan Yûsuf Al-Qaradhāwi, meskipun termasuk salah seorang sarjana muslim kontemporer, ternyata pandangannya cenderung mendukung pandangan dari ulama konservatif, yaitu memandang bahwa semua tambahan dari pokok pinjaman yang dipersyaratkan sebelumnya, adalah riba dan hukumnya haram. Dengan demikian, maka menurutnya, bunga bank juga termasuk dalam tambahan yang dipersyaratkan sebelumnya, karena illat yang terdapat di dalamnya, sama dengan illat riba yang terdapat dalam Al-Qur'an, yaitu bertambahnya harta dari pokok yang dipinjamkan, sebagaimana dinyatakan dalam kalimat "wa in tubtum fa lakûm ru'ūsu amwālikûm. ${ }^{16}$

Namun demikian, keduanya berangkat dari asumsi yang sama, bahwa riba sebagaimana disebutkan dalam Al-Qur'an, adalah riba yang menyebabkan adanya kemudharatan berupa ketidakadilan. Aspek ketidakadilan ini, menjadi wacana penting dalam pemikiran keduanya mengenai riba dan bunga bank. Karena menurut Abdullah Saeed, dalam bunga bank tidak terdapat unsur yang menyebabkan ketidakadilan sekarang ini, sebab orang-orang zaman sekarang lebih pandai dan cermat dalam mengelola pinjaman dari bank. Selain itu, pada saat ini, sudah terdapat banyak peraturan perundang-udangan, yang melindungi hak-hak peminjam maupun pemberi

${ }^{11}$ Abi Ja'far Muhammad bin Jarir At-Thabāri (2001). Tafsir At-Thabāri, cet I juz V (Markazu Al-Buhuts wa Dirasat Al-Arabiyah Al-Islamiyah), p. 39-65.

${ }^{12}$ Ahmad Mustafa Al-Maraghi (1974). Tafsir Al-Maraghi, juz III (Mesir: Mustafa Al-Baby Alhalaby), p. 54-69.

${ }^{13}$ Muhammad Rashid Ridha (tt). Tafsir Al-Manar, jilid III, cet II (ttp: Daarul Fikr), p. 93-116.

${ }^{14}$ Abdullah Saeed (2006). Islamic Banking and Interest..............p. 36.

${ }^{15} \mathrm{Ibid}$, p. 66.

${ }^{16}$ Yûsuf Al-Qaradhāwi (1990). Fawāid al-Bunūk hiyâ al-Ribā al-Harām, cet I (Kairo: Daaru Shahwah), p. 37-38. 
pinjaman, sehingga mustahil terjadi tindak penindasan kreditur kepada debitur, sebagaimana terjadi pada masa lalu. ${ }^{17}$

Dalam sejarah hukum Islam, pandangan keduanya bukanlah hal yang baru, kemudian apa yang menspesifikasikan kedua pemikiran yang ditawarkan oleh Abdullah Saeed dan Yûsuf Al-Qaradhāwi tersebut? Fakta bahwa mereka hidup pada masa sekarang ini, di mana bank Islam sudah berdiri dan beroperasi secara penuh, sehingga bagi sebagian ulama, berdirinya bank Islam tersebut telah menjadikan unsur darurat bagi umat muslim, yang dulu dibolehkan bertransaksi di perbankan konvensional menjadi hilang. Sehingga wajib hukumnya bagi setiap muslim bertransaksi menggunakan bank Islam tersebut. Namun ternyata, masih saja terdapat pandangan yang menyatakan bolehnya bertransaksi menggunakan bank konvensional, yang menurut sebagian ulama haram, karena sistem bunga di bank konvensional adalah riba.

\section{Biografi Abdullah Saeed dan Yusuf Qaradhawi}

Abdullah Saeed adalah seorang professor Studi Arab dan Islam di Universitas Melbourne Australia, sekaligus menjabat sebagai Direktur Pusat Studi Islam Kontemporer di Universitas Mebourne. Abdullah Saeed lahir di Maldives, ${ }^{18}$ pada tanggal 25 September 1964, dan masa kecil hingga remaja dihabiskan di sebuah kota bernama Meedhoo yang merupakan bagian dari kota Addu Atoll. ${ }^{19}$ Ia adalah seorang keturunan suku bangsa Arab Oman yang bermukim di pulau Maldives. Namun kemudian, ia hijrah meninggalkan tanah kelahirannya menuju Saudi Arabia untuk menuntut ilmu di sana.

Di Saudi Arabia, ia belajar bahasa Arab dan memasuki beberapa lembaga pendidikan formal diantaranya, yaitu: Institut Bahasa Arab Dasar dan Institut Bahasa Arab Menengah Madinah, serta Universitas Islam Saudi Arabia. Selanjutnya, Abdullah Saeed meninggalkan Saudi Arabia menuju ke Australia. Di negara Kanguru itu, ia memperoleh beberapa gelar akademik, sampai sekarang ia menetap dan mengajar pada salah satu universitas terkemuka dan terkenal di sana. ${ }^{20}$

${ }^{17}$ Abdullah Saeed (2006), Islamic Banking.............. p. 50.

${ }^{18}$ Maldives adalah sebuah Negara Republik, yaitu: Republik Maldives, tapi sebelumnya adalah pulau Maldives. Negara ini terletak di bagian utara Lautan India, kira-kira $500 \mathrm{~km}$ atu $310 \mathrm{mil} \mathrm{di}$ bagian barat daya India. Negara ini kira-kira terdiri dari 1.000 pulau, namun yang terhuni hanya sekitar 200 pulau. Penduduk yang menghuni Negara ini berasal dari Srilanka, India, Arab dan bahasa yang mereka gunakan adalah bahasa Divehi yang asalnya dari Srilanka. Secara umum penduduk Negara ini memeluk agama Islam, oleh karenanya agama resmi Negara ini adalah agama Islam. Lihat Republic of Maldives (2001). Atlas (Grolier Multimedia Encyclopedia).

19 Abdullah Saeed, Abdullah Saeed Profile, dikutip dari http://www.abdullahsaeed.com/profile/hisstory.htm./accessed 25 Mei 2008.

20 Abdullah Saeed, Curriculum Vitae of Abdullah Saeed, dikutip dari http://www.abdullahsaeed.com/accessed 15 Mei 2009. 
Di Australia, Abdullah Saeed mengajarkan Studi Arab dan Islam pada program strata satu dan program pasca sarjana (program S2 dan S3). Di antara matakuliah yang diajarkan adalah: Ulumu Al-Qur'an, Intelektualisme Muslim dan Modernisasi, Pemerintahan dalam Peradaban Islam, Keuangan dan Perbankan Islam, Hermeneutika Al-Qur'an, Metodologi Hadis, Ushul Fiqh, Kebebasan Beragama di Asia, Islam dan Hak Asasi Manusia, dan Islam dan Muslim di Australia. Selain itu, ia juga terlibat dalam berbagai kelompok dialog antar kepercayaan, yaitu: antara Kristen dan Islam, dan antara Yahudi dan Islam, bahkan ia dikenal sebagai dosen yang ulet dan terkenal karena kemahirannya dalam menguasai beberapa bahasa, di antaranya: bahasa Inggris, Arab, Maldive, Urdu, Indonesia dan Jerman, yang membuatnya sering bepergian ke luar negeri dan telah mengunjungi beberapa Negara, seperti: Amerika Utara, Eropa, Timur Tengah, Asia Selatan, dan Asia Tenggara. Bahkan, ia memiliki banyak sekali relasi pakar dan riset di seluruh dunia.

Sedangkan Yûsuf Al-Qaradhāwi lahir di sebuah desa ${ }^{21}$ di Republik Arab Mesir pada tanggal 9 September pada tahun 1926. Dia lahir dalam keadaan yatim. Oleh sebab itulah, ia kemudian dipelihara oleh pamannya. Pamannya inilah yang mengantarkan Yûsuf Al-Qaradhāwi kecil ke Surau untuk mengaji.

Di tempat itu ia terkenal sebagai seorang anak yang sangat cerdas. Dengan kecerdasannya itu, ia mampu menghafal Al-Qur'an dan menguasai hukum-hukum tajwidnya dengan sangat baik. Itu terjadi pada saat dia masih berada di bawah umur sepuluh tahun. Orang-orang di desa itu telah menjadikan ia sebagai imam dalam usia yang relatif muda, khususnya pada saat shalat subuh. Sedikit orang yang tidak menangis saat shalat menjadi makmumnya.

Setelah itu ia bergabung dengan sekolah cabang Al-Azhār. Dia menyelesaikan sekolah dasar dan menengahnya di lembaga pendidikan itu dan selalu menempati ranking pertama. Kecerdasannya telah tampak semenjak dia kecil, hingga salah seorang gurunya menggelarinya dengan sebutan "Allamah". ${ }^{22}$ Dia meraih ranking kedua untuk tingkat nasional Mesir, pada saat kelulusannya di Sekolah Menengah Umum. ${ }^{23}$

Setelah itu ia masuk Fakultas Ushuluddin di Universitas Al-Azhār. Dari AlAzhār ini ia lulus sebagai Sarjana S1 pada tahun 1952. Dia meraih ranking pertama dari seluruh mahasiswa yang berjumlah seratus delapan puluh orang. Kemudian ia memperoleh ijasah setingkat S2 dan mendapatkan rekomendasi untuk mengajar dari

${ }^{21}$ Nama desa itu adalah Shaf Turab. Desa ini dikenal sebagai desa yang makmur. Di sana dikuburkan salah seorang sahabat Rasulullah yang meninggal terakhir di Mesir, yakni Abdullah bin Haris bin Juz Az-Zuabidi sebagaimana yang ditulis oleh Hafiz Ibnu Hajar dan yang lainnya.

${ }^{22}$ Gelar ini biasanya diberikan pada seseorang yang memiliki ilmu pengetahuan yang luas, khususnya dalam bidang ilmu agama, seperti gelar yang disandang oleh Ibnu Qudama, Muhammad Syaltut dan tokoh-tokoh di Mesir lainnya.

${ }^{23}$ Ishom Talimah (2001). Manhaj Fikih Yûsuf Al-Qardhāwi, terj. Samson Rahman (Jakarta: Pustaka Al-Kautsar), p. 3-4. 
Fakultas Sastra pada tahun 1954. Dia menduduki ranking pertama dari tiga kuliah yang ada di Al-Azhār dengan jumlah mahasiswa sebanyak lima ratus orang.

Pada tahun 1958 dia memperoleh ijasah Diploma dari Ma'had Dirasat AlArābiyah Al-Aliyah dalam bidang Bahasa dan Sastra. Sedangkan pada tahun 1960 ia mendapatkan ijasah setingkat Master di jurusan Ilmu-ilmu Al-Qur'an dan Sunnah di Fakultas Ushuluddin. Pada tahun 1973 dia berhasil meraih gelar Doktor dengan peringkat summa cum laude dengan Disertasi yang berjudul Az-Zakat wa Atsaruha fi Hill al-Masyākil al-Ijtimä'iyyah, yang kemudian disempurnakan menjadi buku Fikih Zakat yang begitu populer hingga sekarang ini. Dia terlambat meraih gelar doktornya karena situasi politik Mesir yang sangat tidak menentu pada masa-masa itu. ${ }^{24}$

Yûsuf Al-Qaradhāwi adalah profil ulama yang tidak saja menggeluti ilmu pengetahuan Islam, tetapi juga mempelajari ilmu pengetahuan umum. Untuk mengkorelasikan ilmu Islam dan ilmu umum, kemudian ia menampilkan Islam dengan opini yang cemerlang. Tetapi ia lebih menonjolkan kecintaannya pada bahasa Arab, karena menurutnya bahasa Arab merupakan bahasa Islam dan sebagai pintu gerbang untuk memahami Al-Qur'an dan Hadis, sekaligus merupakan salah satu syarat untuk melakukan ijtihad. ${ }^{25}$ Menurutnya, untuk menjadi ulama kontemporer tidak saja terbatas menguasai ilmu-ilmu Islam, tetapi juga harus menelusuri buku-buku agama dan trend non-muslim serta membaca kritik-kritik lawannya. ${ }^{26}$

Pemikiran Yûsuf Al-Qaradhāwi pada dasarnya berada pada dua “dunia”, yakni sufi dan fiqh realitas. Ia terkenal sufi, tetapi tetap mengedepankan syari'at, dan dari pemahaman syari'ah inilah yang kemudian mengarahkan sosoknya terhadap sikap yang tanggap terhadap problem sosial. Dari sikap concern-nya terhadap lehidupan sosial ini, telah membawanya menjadi pemerhati diberbagai bidang keilmuan, kemudian ditulisnya ke dalam beberapa buku. ${ }^{27}$

\section{Pandangan Keduanya Seputar Riba}

\section{A. Pemikiran Abdullah Saeed}

Dalam pembahasannya mengenai riba, Abdullah Saeed secara langsung maupun tidak langsung mengelompokkan pemikiran dan pendapat umat Islam ke dalam dua kelompok besar. Kelompok pertama adalah kelompok umat Islam yang berusaha mempraktikkan secara konsisten dan tekstual akan haramnya riba sebagaimana telah mereka dapatkan melalui pemahaman mereka mengenai hal itu dalam Al-Qur'an dan Hadis, sehingga berdampak pada keinginan mereka untuk mendirikan sebuah lembaga keuangan dan perbankan yang bebas bunga (interestfree banking) dan bebas dari penentuan keuntungan dari awal (pre-determined

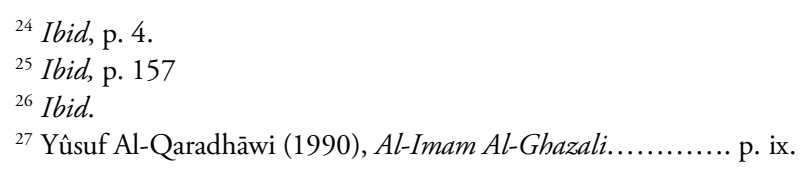


return) dengan berpedoman pada metode bagi hasil (profit and loss sharing/PLS) sesuai dengan ajaran Islam. ${ }^{28}$

Kelompok ini menurutnya, digawangi oleh para tokoh konservatif yang menekankan pemahamannya untuk tetap berpegang pada aturan formal yang terdapat dalam Al-Qur'an dan Hadis, sehingga menginterpretasikan bunga bank (interest) sebagai riba. Mereka mengikuti pemahaman klasik yang mengatakan bahwa setiap keuntungan yang diperoleh para pemberi pinjaman (lender) atas pinjamannya adalah riba. berdasarkan pandangan ini, maka setiap peningkatan dalam pinjaman yang menambah perolehan pemberi pinjaman (kreditur) termasuk riba.

Sedangkan kelompok kedua, adalah kelompok yang memandang bahwa sebab pelarangan riba adalah karena menimbulkan ketidakadilan, sebagaimana dalam Al-Qur'an disebutkan "lâ taźlimûna wa lâ tuźlamûn" (kamu tidak menganiaya dan tidak pula teraniaya). Menurut Abdullah Saeed, pandangan mereka ini juga didasarkan pada pandangan para ulama klasik, di antaranya seperti Razi, Ibn Qayyim, dan Ibnu Taimiyah. Mungutip dari Ibn Qayyim, Abdullah Saeed mengatakan, bahwa di antara sebab-sebab larangan riba adalah bahwa berkaitan dengan aspek moral. Berdasarkan praktek riba yang terjadi pada masa pra-Islam, dalam banyak kasus para peminjam (debitur) adalah kalangan miskin yang tidak punya pilihan lagi, kecuali menangguhkan pembayaran hutangnya. Berdasarkan alasan ini, menurut kelompok ini larangan riba secara moral menopang dalam perubahan sosial-ekonomi masyarakat. ${ }^{29}$

Menurut Abdullah Saeed, dilarangnya riba dalam Islam seperti yang terdapat dalam Al-Qur'an, merupakan suatu bentuk pelarangan yang dilatarbelakangi oleh beberapa sebab yang terjadi pada masyarakat Makah saat itu. Sebelum riba di larang, Al-Qur'an sudah terlebih dahulu menyeru masyarakat yang mampu untuk membantu orang-orang yang tidak mampu seperti orang-orang fakir, miskin dan anak-anak yatim. Oleh sebab itulah, dalam Al-Qur'an banyak dijumpai ayat-ayat yang mengajurkan atau bahkan mewajibkan manusia untuk menafkahkan hartanya. ${ }^{30}$

Dalam hal ini, Al-Qur'an secara tegas menekankan pentingnya membantu orang-orang lemah tersebut dengan dua cara, yang pertama adalah shadaqah yang bersifat anjuran sukarela, dan yang kedua adalah zakat yang bersifat memaksa (wajib). Al-Qur'an juga mengingatkan kembali pada manusia agar memenuhi anjuran dan perintah tersebut, sebab harta yang diberikan Allah kepada manusia hanyalah sebagai titipan (amanah) dan sekaligus sebagai cobaan. Atas dasar itulah, upaya mengumpulkan harta kekayaan dengan tidak

\footnotetext{
${ }^{28}$ Abdullah Saeed (2006). Islamic Bangking and Interest.............. p. 1-2.

${ }^{29}$ Ibid. p. 41.

${ }^{30}$ Abdullah Saeed (2006). Islamic Banking and Interest........... p. 17-20.
} 
mempertimbangkan kepentingan sosial dan masyarakat ekonomi lemah tidak akan mendapatkan keselamatan baik di dunia maupun akhirat, atau dengan kata lain, harta itu pada hakikatnya tidak bernilai di sisi Allah. ${ }^{31}$

Berdasarkan pemahaman di atas, menurut Abdullah Saeed, Al-Qur'an memberikan perhatian yang mendalam terhadap masyarakat yang secara ekonomi lemah dan menekankan untuk membantu kebutuhan finansial mereka, dengan tanpa memberi tambahan beban penderitaan. Dalam konteks ini menunjukkan bahwa tuntunan yang demikian itu diperintahkan dalam kasus apa bila pihak peminjam terpaksa meminjam uang guna untuk mencukupi kebutuhan primernya. Di sini terlihat bahwa, tidak ada indikasi bahwa tuntunan ini berlaku terhadap kasus pinjaman bagi orang-orang kaya yang digunakan untuk tujuan perdagangan dan bidang komersial lainnya. Dengan kata lain, digunakan selain untuk bantuan yang sifatnya tidak mengandung unsur pri-kemanusiaan (non-humanitarian). ${ }^{32}$

Pada rangkaian ayat terakhir yang turun Q.S. Al-Baqarah (2): 275-280, menurut Abdullah Saeed istilah riba yang terdapat di dalamnya tidak berbeda dengan istilah riba yang turun pada ayat-ayat sebelumnya. Dengan merujuk pada pendapat Rashîd Ridhâ ${ }^{33}$ ia menjelaskan, "Elemen "al" (definite article) dalam term riba ayat ini menunjukkan adanya indikasi pengetahuan dan kelaziman, maksudnya, janganlah mengkonsumsi riba yang sudah lazim bagimu, yang dipraktekkan pada masa pra-Islam.

Hal ini diperkuat lagi dengan melihat pada sebab turunnya ayat ini, menurut As-Suyûthi (w. $911 \mathrm{H}$ ), ayat ini turun berkaitan dengan Bani Amr bin Auf dari Tsaqif dan Bani Mughirah yang telah masuk Islam, yang mana pada masa sebelumnya, Bani Amr bin Auf dan Bani Mughirah sering melakukan transaksi secara riba. Sehingga, pada saat itu masih terdapat riba pada mereka, dan Bani Amr bin Auf menagih riba tersebut, namun mereka menolaknya, dengan alasan bahwa mereka telah masuk Islam, dan riba dilarang dalam Islam. Hal ini kemudian dicatat oleh 'Utab bin Usaid yang kemudian menyampaikan berita ini pada Rasulullah, maka turunlah ayat ini. ${ }^{34}$

Sedangkan Thābari menyebutkan, bahwa ayat ini turun pada Al-Abbās bin Abdul Muthālib dan seseorang dari Bani Mughirah yang bekerjasama semenjak masa jahiliyah meminjamkan uang kepada orang-orang Tsāqif dengan riba, maka ketika Islam datang, mereka berdua memiliki banyak sekali harta hasil dari riba dan

\footnotetext{
${ }^{31}$ Ibid.

32 Ibid, p. 37-39.

${ }^{33}$ Muhammad Rashid Ridha (tt). Tafsir Al-manar.............. p. 94.

${ }^{34}$ Jalaludin Abdurahman bin Abi Bakr As-Suyûthi (2000). Ad-durus al-Mantsur fi Tafsiri alMa'tsur, cet I (Beirut: Daarul Kutub Al-Ilmiah), p. 643.
} 
juga riba yang belum dipungut, maka turunlah ayat "maka tinggalkanlah sisa riba". ${ }^{35}$

Pemaparan di atas sudah cukup menjelaskan pada kita, bahwa hal pertama yang harus diperhatikan untuk memahami peristilahan riba yang terdapat dalam Al-Qur'an, menurut Abdullah Saeed adalah latar sosial masyarakat pada saat itu, di mana sebagian besar dari mereka melakukan pinjaman hanya untuk menutupi kebutuhan pokok mereka. Selain itu, penekanan Al-Qur'an juga terlihat pada bentuk atau jenis riba yang dilarang adalah jenis riba yang sudah lazim dilakukan oleh mereka semenjak masa jahilyah, yaitu riba yang berlipatganda. Di mana riba ini benar-benar menjadikan orang-orang yang berhutang menjadi obyek eksploitasi orang-orang yang memberikan pinjaman, sehingga mereka menjadi sangat lemah bahkan tidak mampu membayar hutang-hutang tersebut. Pernyataan penting, yang dapat dijadikan kata kunci dalam kaitanya dengan perbincangan riba dalam Al-Qur'an, yaitu yang terdapat dalam surat Al-Baqarah (2): 279, yang secara jelas menunjukkan sifat pelarangannya. Pertama adalah pernyataan dari kalimat " $f a$ lakûm ru'üsu amwālikûm", yang kemudian disusul dengan pernyataan yang kedua, yang terdapat dalam kalimat "là tuźlimūna wa là tuźlàmūn". ${ }^{36}$

Pernyataan pertama menunjukkan, bahwa penarikan pokok harta yang dipinjamkan oleh kreditur, bukan merupakan perbuatan yang aniaya, baik terhadap diri sendiri maupun debitur. Kedua, masing-masing pernyataan di atas menunjukkan indikasi yang saling berkaitan, satu sama lain tidak dapat bediri sendiri tanpa dukungan yang lainnya. Jika kedua pernyataan tersebut dipisah, dengan cara mengabaikan salah satu darinya, maka akan terjadi pengkaburan makna dari maksud pesan Al-Qur'an tersebut.

Sehingga sungguh disayangkan, apabila dalam menafsirkannya hanya memperhatikan pernyataan "fa lakûm ru'üsu amwälikûm" saja, dan terlebih lagi bila sampai mengabaikan pernyataan "là taźlimūna wa là tuźlāmūn". Pernyataan kedua, pada dasarnya merupakan kerangka metodologi yang hampir diikuti oleh seluruh mazhab hukum Islam, sekaligus sebagai unsur pokok, untuk mengetahui setiap perintah dan larangan dalam Al-Qur'an, yang dihasilkan melalui interpretasi yang mendalam terhadap makna yang relevan dari sebuah teks, juga dapat memberi perhatian terhadap penyebab-penyebab utama dari munculnya larangan dan perintah tersebut. ${ }^{37}$

Abdullah Saeed memandang, tidaklah dapat diabaikan bahwa penekanan terhadap rasionalitas dalam mengetahui larangan riba sangatlah penting, baik bersumber dari penafsiran maupun dalam bentuk keputusan (fatwa) ulama. Sebab

${ }^{35}$ Abi Ja'far Muhammad bin Jarir At-Thabāri (2001). Tafsir At-Thabāri, Jami' al-Bayan an Ta'wili Ayi al-Qur'an, cet I Juz V (Markazu al-Buhuts wa Dirasat al-Arabiyah Al-Islamiyah), p. 49-50.

${ }^{36}$ Abdullah Saeed (2006). Islamic Banking and Interest.............. p. 26.

${ }^{37}$ Ibid, p. 27. 
dalam hal ini, keputusan para ulama merupakan sesuatu yang legal, yang berdasarkan pada kandungan makna relevan dari teks yang sarat akan kandungan aspek-aspek pelarangannya. Dengan demikian pernyataan " $f a$ lakûm ru'ūsu amwālikûm" telah diberi penekanan melalui penjelasan "lā taźlimūna wa lā tuźlāmūn" yang digunakan secara beriringan.

Dari pernyataannya di atas, nampaknya Abdullah Saeed ingin menyatakan, bahwa penekanan makna riba melalui pernyataan kalimat " fa lakûm ru'ūsu amwālikîm" yang kemudian disusul dengan kalimat selanjutnya "là taźlimūna wa là tuźlāmūn”, memberikan ruang bagi pemahaman lain, selain dari pemahaman yang sudah ada selama ini. Dalam kasus ini Abdullah Saeed berusaha memberikan gambaran, terhadap pinjaman yang diajukan oleh orang-orang kaya, yang mana pinjaman tersebut bukan digunakan untuk memenuhi kebutuhan pokoknya, melainkan untuk menjalankan usahanya. Secara tidak langsung, Abdullah Saeed ingin menyatakan, bahwa pinjaman yang demikian bukanlah termasuk dari jenis pinjaman yang bersifat menganiaya, dan inilah yang rasional sesuai dengan perkembangan yang terjadi sekarang ini.

Abdullah Saeed melihat, bahwa dalam praktiknya, sistem bunga dalam perbankan konvensional saat ini, tidaklah termasuk ke dalam jenis bunga yang menyebabkan terjadinya ketidakadilan, apalagi sampai pada terjadinya penindasan dan penganiayaan yang dilakukan oleh kreditur kepada debitur. Oleh sebab itu, bunga bank yang demikian bukanlah termasuk ke dalam riba yang dilarang, sebab tidak menimbulkan efek yang buruk, yang menjadi tujuan utama dalam aspek pelarangan riba dalam Islam. ${ }^{38}$

Lebih jauh ia mengatakan, bahwa sistem perbankan konvensional dengan pinjaman berbunganya, telah memiliki andil yang besar dalam mendorong kemajuan ekonomi dunia, sebab banyak manfaat yang bisa didapatkan darinya. Bolehnya pinjaman berbunga pada bank konvensional, menurut Abdullah Saeed didasarkan pada beberapa alasan, yang dapat diringkas sebagai berikut: ${ }^{39}$

1. Bunga bank yang ada saat ini tidak menimbulkan terjadinya ketidakadilan, sebagaimana yang terjadi dalam praktik riba yang ada pada masa jahiliyah.

2. Bunga bank memiliki manfaat yang besar dalam mendorong tercapainya kemajuan suatu masyarakat.

3. Transaksi pinjam-meminjam dalam sistem perbankan dilakukan secara jelas, terbuka dan dilindungi oleh undang-undang, sehingga tidak memungkinkan terjadinya penindasan oleh kreditur terhadap debitur.

\footnotetext{
${ }^{38}$ Abdullah Saeed (2006). Islamic Banking............... p. 75.

${ }^{39} \mathrm{Ibid}$, p. 51 dan 52.
} 
4. Pada masa sekarang ini, seorang yang akan mengajukan suatu pinjaman kepada bank, sudah memperhitungkan dengan teliti, apakah ia akan dapat mengembalikan modal pinjaman beserta bunganya.

Selain berlandaskan pada alasan-alasan tersebut, persetujuan Abdullah Saeed terhadap bolehnya bunga bank, ditemukan dalam pemikiran-pemikirannya yang lebih condong dan menyetujui pemikiran-pemikiran beberapa ulama modernis lainnya, yang membolehkan pinjaman berbunga di bank konvensional. Seperti pandangan Fazlur Rahman, yang lebih menekankan aspek kontekstual antara pinjaman pada masa jahiliyah dengan masa kini yang sudah berbeda konteks penerapannya, ${ }^{40}$ pandangan Rashid Ridha dan Muhammad Abduh yang memandang bahwa sistem perbankan saat ini mirip dengan sistem perkongsian dalam Islam, dan lembaga perbankan menjadi kebutuhan yang sangat vital, sebagai media bagi tercapainya kemajuan dalam suatu masyarakat. ${ }^{41}$ Demikian juga dengan pandangan Sanhuri yang lebih melihat pada faktor berlipatgandanya riba pada masa jahiliyah, yang tidak identik dengan bunga bank konvensional yang ada sekarang ini. ${ }^{42}$

Abdullah Saeed juga mendukung pernyataan dari Doualibi yang membedakan antara pinjaman produktif dan konsumtif, yang menurutnya pada saat ini, pinjaman di perbankan yang dilakukan oleh sebagian besar orang, digunakan untuk keperluan produktif. ${ }^{43}$ Begitu juga dengan pandanganpandangan ulama modernis lainnya, seperti mereka yang membedakan antara bunga yang dilakukan oleh individual dan institusional, pemaknaan bunga, apakah bunga itu interest atau usury, serta perbedaan antara bunga nominal atau real yang berkaitan dengan inflasi dan deflasi. Semua pendapat tadi menurut Abdullah Saeed lebih sesuai dengan situasi dan kondisi sekarang ini, sehingga lebih rasional, bila bunga bank merupakan hal yang legal menurut pemikirannya. ${ }^{44}$

\section{B. Argumentasi Yusuf Qaradhawi}

Sementara itu, dalam mukadimah bukunya, Fawāid al-Bunūk hiyâ alRibā al-Harām, Yûsuf Al-Qaradhāwi secara eksplisit menyatakan, bahwa pada dasarnya permasalahan seputar riba, adalah sebuah permasalahan yang sudah selesai pembahasannya semenjak seperempat abad yang lalu, hal itu dia utarakan, ketika mengisi sebuah seminar yang diselenggarakan oleh Forum Ekonomi Islam disebuah tempat di Kairo Mesir. ${ }^{45}$

\footnotetext{
${ }^{40}$ Abdullah Saeed (2006). Islamic Banking............. p. 75.

${ }^{41}$ Ibid, p. 76.

42 Ibid, p. 77.

43 Ibid, p. 79.

${ }^{44}$ Ibid, p. $81-83$.

45 Yûsuf Al-Qaradhāwi (1990). Fawāid al-Bunūk hiyâ al-Ribā al-Harām, cet I (Kairo: Daaru
} Shahwah), p.13. 
Sebab menurutnya, Islam secara tegas telah mengharamkan riba dan secara keras melarangnya. Pengharaman dan pelarangan itu, berdasarkan hukum dari nash-nash yang pasti (qath'i) di dalam Al-Qur'an dan sunnah, yang tidak bisa lagi diinterpretasikan ataupun ditakwilkan meskipun dengan alasan ijtihad dan pembaharuan hukum (tajdid). Sebab tidak ada ijtihad dalam setiap permasalahan yang telah terdapat kepastian, yang telah ditetapkan hukumnya oleh dalil (qath'i tsubut wa dilälah), dan secara ijma' seluruh umat baik dari generasi yang terdahulu (salaf), maupun yang generasi belakangan (khalaf). ${ }^{46}$

Yûsuf Al-Qaradhāwi mengatakan, bahwa pada dasarnya Islam dalam mensikapi (menghukumi) masalah riba ini, tidak berbeda jauh dengan sikap yang diperlihatkan oleh agama-agama samawi lainnya. Pada agama Yahudi misalnya, terdapat aturan yang jelas mengenai hal ini, sebagaimana disebutkan dalam kitab Perjanjian Lama, "Jika temanmu meminta pinjaman, maka penuhilah (berikanlah), janganlah menuntut darinya keuntungan juga manfaat" (Eksodus, ayat 24 bab 22). ${ }^{47}$

Juga dalam agama Kristen, sebagaimana terdapat dalam kitab Injil Lukas, "Berbuat baiklah, dan pinjamkanlah dan janganlah kalian menunggu untuk (mengambil) pembayarannya, sehingga (itu) menjadi pahala yang banyak bagi kalian" (Lukas, ayat 24-25 bab 6).

Namun disayangkan, telah terjadi penyelewengan dalam penafsiran isi dari kitab Perjanjian Lama, yang menjadikan kata "temanmu" sebagai sebuah pengkhususan, yang hanya berlaku bagi orang-orang Yahudi, dan kemudian dijelaskan dalam kitab Ulangan "Bagi orang-orang asing engkau boleh meminjamkan dengan riba, tetapi bagi saudaramu (sesama Yahudi) janganlah engkau pinjamkan dengan riba", (Ulangan, ayat 23 bab 19). ${ }^{48}$

Islam, telah melarang setiap jalan yang dapat menimbulkan perkembangan harta melalui jalan riba, sebab Islam telah mengharamkan riba, baik itu sedikit ataupun banyak, dan begitulah pula yang telah dikecam oleh Al-Qur'an terhadap orang-orang Yahudi yang masih saja mengambil riba, padahal mereka telah dilarang untuk itu. Hal ini sebagaimana telah kita temukan dalam beberapa ayat dari surat Al-Baqarah (2): 275-281, yang turun pada akhir-akhir periode penurunan wahyu, yang menjelaskan tentang hal tersebut. ${ }^{49}$

Untuk mengetahui dan memahami aspek keharaman dan pelarangan riba ini, cukuplah bagi setiap muslim membaca ayat tersebut di atas, dengan membacanya saja, niscaya kita akan merasakan betapa jantung kita bergetar hebat,

\footnotetext{
${ }^{46}$ Ibid, p. 14.

47 Yûsuf Al-Qaradhāwi (1990). Al-Halāl wa Al-Harām fi Al-Islam, Cet. VX (Beirut: Maktabah

${ }^{48}$ Ibid, p. 242.

${ }^{49}$ Ibid, p. 241.
} Al-Islami), p. 241. 
disebabkan karena kerasnya ancaman yang dijanjikan Allah dalam ayat tersebut. Padahal ayat-ayat tersebut merupakan ayat-ayat muhakamat ${ }^{50}$-yang ketentuan hukumnya sudah pasti dan tidak membutuhkan interpretasi lebih jauh. ${ }^{51}$

Lebih lanjut, menurut pandangannya, elemen "al-ma'rifah" (the definite article) dalam kata "al-ribä" baik sebagai lil 'ahdi (keterangan yang menunjukkan kelaziman), atau sebagai lil jinsi (keterangan yang menunjukkan jenis tertentu) ataupun sebagai lil istighraq (keterangan yang menunjukkan keumuman), maksudnya sudah jelas dan terang, yaitu mengharamkan seluruh jenis riba. Seandainya pengertian riba masih kabur, niscaya Allah akan menerangan kepada mereka. Sedangkan ayat ini tidak lagi mendefinisikan kata riba, mengingat sudah lazim dikenal secara umum. Padahal penjelasan yang datang lebih akhir dari waktu yang dibutuhkan, tidak dibolehkan dalam kaidah hukum Islam, sehingga dengan demikian, riba yang dimaksud tidak memerlukan penjelasan lebih jauh. ${ }^{52}$

Mengenai penjelasan riba dalam ungkapan berlipat ganda (adh'äfan mudhäâfatan, Q.S. Ali Imran (3): 130), Yûsuf Al-Qaradhāwi melihatnya bukanlah sebagai syarat dari pelarangan riba. Sebagaimana diketahui, bagi orang yang ahli dalam bidang bahasa Arab, dan memahami retorikanya (uslüb, bentuk pluralnya asālib), mengetahui bahwa sifat riba yang disebutkan dalam ayat ini adalah dalam konteks menerangkan kondisi objektif dan sekaligus kecaman terhadapnya. Mereka telah sampai pada tingkatan ini, dengan mempraktikkan riba yang berlipatganda.

Pada intinya, Yûsuf Al-Qaradhāwi ingin mengatakan bahwa aspek pelarangan riba dalam al-Qur'an tidak terbatas pada apa yang dipahami oleh sebagian orang terhadap riba yang berlipatganda saja, sebab itu semua hanya merupakan gaya bahasa dari al-Qur'an dalam menggambarkan betapa riba pada masa jahiliyah telah begitu buruknya, hingga mencapai bentuk yang berlipatganda. Maka baginya, pernyataan berlipatganda ini bukanlah sesuatu yang penting dalam konteks pelarangan riba, sebab telah jelas bahwa yang riba yang dilarang dalam al-

${ }^{50}$ Yûsuf Al-Qaradhāwi (1990). Fawāid al-Bunūk. p. 14 .

${ }^{51}$ Muhkam atau bentuk pluralnya Muhakamat menurut terminology Ushul Fiqh ialah sesuatu yang menunjukkan pada artinya, dan tidak menerima pembatalan serta pergantian dengan sendirinya secara jelas dan sama sekali tidak mengandung takwil, pengertian tidak mengandung takwil adalah tidak menghendaki arti lain yang bukan arti dzahir-nya. Sebab ia dijelaskan dan ditafsirkan dengan penafsiran yang tidak memungkinkan adanya pen-takwil-an, tidak pula menerima penghapusan (naskh) pada masa kerasulan Muhammad dan masa kekosongan turunya wahyu, dan atau sesudahnya. Karena hukum-hukum yang terdapat di dalamnya adakalanya berupa kaidah-kaidah hukum agama yang bersifat asasi dan tidak dapat digantikan, atau terdiri dari prinsip-prinsip keutamaan yang tidak berubah lantaran perubahan situasi dan kondisi, atau juga berupa hukum furu', namun terbukti bahwa dikuatkan oleh syara'. Lihat Abdul Wahab Khalaf (1968). Ilmu Ushul Al-Figh, Cet IIX (Kairo: Dakwah Islamiyah Syabab Al-Azhar Misr),

${ }^{52}$ Ibid, p. 45. 
Qur'an adalah setiap penambahan yang terdapat dalam peminjaman, baik itu besar atau kecil yang telah ditentukan terlebih dahulu sebelumnya. ${ }^{53}$

\section{Penutup}

Dari analisa dan pembahasan mengenai pandangan dan pemikiran kedua tokoh di atas, meskipun hampir sebagian besar memperlihatkan adanya pandangan yang kontradiktif, namun pada dasarnya, dari seluruh pandangan dan argumentasiargumentasinya tersebut, masih ada beberapa persamaan persepsi dari keduanya. Di bawah ini akan disajikan antara persamaan dan perbedaan pandangan keduanya, adalah sebagai berikut:

\section{A. Persamaan Pandangan}

1. Dalam membahas mengenai riba dan pemahaman mereka akan riba, keduanya sama-sama berangkat dari dasar pemahaman nash, baik itu dari nash-nash al-Qur'an maupun sunnah.

2. Dalam melakukan interpretasi mengenai riba dalam nash-nash tersebut, keduanya memiliki tujuan akhir yang sama, yaitu supaya interpretasi yang mereka hasilkan dapat memberikan sumbangsih bagi terciptanya kemaslahatan umat, sehingga umat tidak lagi berada dalam kebimbangan ketika menentukan suatu transaksi yang masih mengandung keraguan akan boleh dan tidaknya secara hukum

3. Pada dasarnya keduanya memiliki pandangan, bahwa riba merupakan sesuatu yang mutlak dilarang dalam Islam dan hukumnya haram. Karena praktik riba hanya akan menciptakan suatu tatanan dalam masyarakat menjadi rusak, timbulnya ketidakadilan dan terjadinya penganiayaan oleh sekelompok orang terhadap sekelompok orang lainnya.

4. Keduanya juga sama-sama memiliki pandangan, bahwa pembahasan yang mereka lakukan dalam kajian mereka masing-masing adalah pembahasan mengenai riba jenis nasi'ah atau jahiliyah yang sudah jelas-jelas dilarang dalam al-Qur'an maupun sunnah, sedangkan untuk riba fadhl, mereka tidak membahasnya secara lebih luas dalam bukunya masing-masing.

5. Dalam kaitannya dengan argumentasi bahwa riba yang dilarang dan dibolehkan adalah riba jenis produktif dan konsumtif, keduanya tidak memiliki landasan atau keterangan yang kuat untuk mengklaim bahwa pandangan merekalah yang paling benar. Sebab memang tidak ada riwayat atau keterangan, yang menyebutkan bahwa riba yang terjadi pada masa jahiliyah itu adalah jenis riba konsumtif bukan jenis riba yang produktif, atau malah sebaliknya.

${ }^{53}$ Sebagai perbandingan lihat: Sayyid Muhammad Qutb (1992). Fi Dzilali Al-Qur'an............. p. 325 . 


\section{B. Perbedaan pandangan.}

1. Perbedaan pandangan dalam menentukan aspek apa sebenarnya yang terkandung dalam al-Qur'an dan sunnah dalam pelarangan riba. Abdullah Saeed lebih cenderung memandang aspek penekanan moral, sedangkan Yûsuf Al-Qaradhāwi lebih melihat dari aspek formalnya, atau apa yang ada dalam $d z a h i r$ ayat.

2. Perbedaan pandangan pada poin pertama di atas, menyebabkan terjadinya perbedaan pula dalam menentukan bagian pernyataan mana dalam al-Qur'an yang sebenarnya harus dijadikan dasar pijakan utama dalam memahami pelarangan riba. Abdullah Saeed cenderung melihat pernyataan lā taźlimūna wa là tuźlāmūn sebagai titik tolaknya dalam memahami pelarangan ini, sementar Yûsuf Al-Qaradhāwi lebih melihat pada pernyataan fa lakûm ru'üsu amwālikîm sebagai acuan utamanya.

3. Perbedaan dalam menentukan landasan anaolgi apakah yang semestinya dipakai dalam membahas masalah pelarangan riba ini, Abdullah Saeed lebih melihat hikmah sebagai landasan analoginya, sebab menurutnya illat memiliki banyak kelemahan, sebaliknya Yûsuf Al-Qaradhāwi cenderung menggunakan illat sebagai landasan analoginya.

4. Perbedaan dalam memandang wacana ketidakadilan, menurut Abdullah Saeed, ketidakadilan hanya terdapat pada riba yang terdapat pada masa jahiliyah, karena terjadinya penindasan kriditur kepada debitur, hingga menyebabkan perbudakan, sedangkan transaksi pinjaman berbunga di bank saat ini, mustahil akan menyebabkan penindasan, lebih-lebih perbudakan oleh kreditur kepada debitur. Sedangkan menurut Yûsuf AlQaradhāwi, keadilan hanya akan tercapai, bila antara pemilik modal dan pengusaha, berbagi resiko atas keuntungan maupun kerugian, dari modal yang digunakan dalam usaha tersebut.

5. Perbedaan-perbedaan dalam menentukan landasan pengharaman dalam menghukumi bunga bank, menurut Yûsuf Al-Qaradhāwi, bunga bank sama dengan riba yang dilarang dalam Islam, karena berpijak pada statemen bahwa setiap penambahan dalam transaksi pinjaman adalah dilarang. Sedangkan Abdullah Saeed memandang, sepanjang pinjaman tersebut tidak menyebabkan ketidakadilan, maka pinjaman tersebut dibolehkan, dan demikian pula sistem pinjaman dalam bank, meskipun jelas-jelas terdapat bunga di dalamnya.

6. Yûsuf Al-Qaradhāwi lebih melihat kemudharatan pinjaman berbunga dari segi mikro ekonomi, hal itu terlihat dari pemaparannya mengenai kemudharatan-kemudharatan pinjaman berbunga yang lebih mengarah kepada individual orang per orangnya. Sedangkan Abdullah Saeed, lebih melihat manfaat dari pinjaman berbunga secara makro ekonomi suatu 
negara. Di mana pada saat ini, bagi negara-negara yang tengah berkembang, kebutuhan akan pinjaman untuk melakukan pembangunan pada sektor-sektor utama sangatlah dibutuhkan. Terlebih bila pinjaman tersebut dapat meningkatkan kesejahteraan rakyatnya, dan disertai dengan pengelolaan yang baik, sehingga dampak manfaat dari pinjaman berbunga tersebut akan lebih besar ketimbang dampak mudharatnya.

Perkembangan pada masa modern sekarang yang begitu cepat dan kompleks, merupakan sebuah tantangan sekaligus kesempatan bagi umat Islam untuk menemukan jatidirinya sebagai seorang muslim. Dalam bidang ekonomi, munculnya perbankan Islam patut kita apresiasi, sebab dengan adanya perbankan tersebut, telah mengangkat status umat yang sebelumnya berada dalam kondisi darurat, menjadi keadaan yang kembali normal, dalam kaitanya dengan hubungan transaksi pinjam-meminjam dana di perbankan. Sehingga ketika telah adanya bank Islam, semestinya umat Islam menggunakan fasilitas yang sesuai dengan prinsip-prinsip Islam, terutama dalam bermu'amalah.

\section{DAFTAR PUSTAKA}

http://www.abdullahsaeed.com/profile/hisstory.htm./accessed 25 Mei 2008.

http://www.abdullahsaeed.com/accessed 15 Mei 2009.

Al-Jhassās (tt). Ahkam Al-Qur'an (Beirut: Daarul Kutub Al-Ilmiah).

Khalaf, Abdul Wahab (1968). Ilmu Ushul Al-Figh (Kairo: Dakwah Islamiyah Syabab Al-Azhar Misr).

Al-Maraghi (1974). Tafsir Al-Maraghi (Mesir: Mustafa Al-Baby Al-halaby).

Al-Maûdūdi, Abu A’la (tt). Al-Riba (Hyderabad: Daarul Fakir).

Nasution, Khoiruddin (1996). Riba dan Poligami: Sebuah Studi atas Pemikiran Muhammad Abduh (Yogyakarta: Pustaka Pelajar).

Al-Qaradhāwi, Yûsuf (1990). Fawāid al-Bunūk hiyâa al-Ribā al-Harām (Kairo: Daaru Shahwah).

Al-Qaradhāwi, Yûsuf (1990). Al-Halāl wa Al-Harām fi Al-Islam (Beirut: Maktabah AlIslami).

Al-Qurthūbi (1993). Al-Jami' Al-Ahkam min Al-Qur'an (Beirut: Daarul Kutub AlIlmiah).

Qutb, Sayyid Muhammad (1992). Fi Dzilali Al-Qur'an (ttp: Daarus Syuruk).

Rahman, Fazlur (1985). Islam and Modernity (Chicago: The University of Chicago Press).

Republic of Maldives (2001). Atlas (Grolier Multimedia Encyclopedia).

Ridha, Muhammad Rashid (tt). Tafsir Al-Manar (ttp: Daarul Fikr). 
Wartoyo: Bunga Bank...

Saeed, Abdullah (2006). Islamic Thought: An Intoduction (New York: Routledge).

As-Shiddiqi, Muhammad Nejatullah (1983). Banking Without Interest (Liecester: Islamic Foundation).

As-Suyûthi (2000). Ad-Durr al-Mantsur fi Tafsiri al-Ma'tsur (Beirut: Daarul Kutub AlIlmiah).

As-Syaukani (2002). Fathul Qadir (Riyadh, Maktabah Ar-Rusyd).

Talimah, Ishom (2001). Manhaj Fikih Yûsuf Al-Qardhāwi, terj. Samson Rahman (Jakarta: Pustaka Al-Kautsar).

At-Thabāri (2001). Tafsir At-Thabāri (Markazu Al-Buhuts wa Dirasat Al-Arabiyah AlIslamiyah). 